\title{
Measuring the Severity of a Banking Crisis and Finding Its Associated Factors: How Are the Factors Different for Simple and Severe Banking Crises?
}

\author{
Anichul Hoque Khan, Hasnat Dewan* \\ Department of Economics, Thompson Rivers University, Kamloops, Canada \\ Email: ${ }^{\text {hdewan@tru.ca }}$
}

Received 18 October 2014; revised 27 November 2014; accepted 10 December 2014

Copyright (C) 2014 by authors and Scientific Research Publishing Inc.

This work is licensed under the Creative Commons Attribution International License (CC BY). http://creativecommons.org/licenses/by/4.0/

\section{(c) (i) Open Access}

\begin{abstract}
This study measures the severity of a banking crisis by using its duration and the cost. Using this new methodology, we find that the factors associated with a severe banking crisis are not quite the same as those associated with a simple banking crisis. An ordered logit model and a large panel data set were used for this study. One of our major findings is that there exists a four-year time lag between an economic boom, or financial system liberalization, and the occurrence of a severe banking crisis in a country. This indicates that banking problems start much earlier than the time when they are revealed as banking crises. This study also finds that the lower the remains of a past banking crisis, the higher the probability of a severe banking crisis. It could be due to less-attentiveness of banking sector policy-makers with elapsed time. A high rate of inflation, existence of an explicit deposit insurance scheme, and a weak institutional environment are found to be common factors positively associated with both simple and severe banking crisis.
\end{abstract}

\section{Keywords}

Banking Crises, Severe Banking Crisis, Economic Boom, Liberalized Financial System

\section{Introduction}

At first, this paper proposes a new methodology to measure the severity of banking crisis, and then finds the

\footnotetext{
${ }^{*}$ Corresponding author.
}

How to cite this paper: Khan, A.H. and Dewan, H. (2014) Measuring the Severity of a Banking Crisis and Finding Its Associated Factors: How Are the Factors Different for Simple and Severe Banking Crises? Theoretical Economics Letters, 4, 857866. http://dx.doi.org/10.4236/tel.2014.49109 
factors associated with a severe banking crisis. Most of the previous studies ${ }^{1}$ defined a banking crisis incidence depending on meeting one or more of the criteria such as a threshold level of non-performing loans, a threshold amount of assets of insolvent banks, a threshold level of cost of rescue operation from a crisis, or other kinds of banking sector problems. Those studies used a dummy variable $(0,1)$ to define the incidence of a banking crisis, and then found the factors associated with the crisis. However, all banking crises are not alike. They are different in terms of severity. Hence, unlike previous studies, we define a banking crisis with its severity level by taking an arithmetic average of two factors - crisis-duration and cost-ranking as determined by the percentage of GDP loss due to the banking crisis (see Table A1 in the Appendix). We use an ordinal variable to define different severity levels of banking crises, and then attempt to identify the associated factors or explanatory variables.

A number of studies have examined the factors associated with a banking crisis. Demirguc-Kunt and Detragiache [2] attempted to identify the factors causing a banking crisis. They focused on various macroeconomic, financial market, and institutional variables. Their study suggests that a banking crisis tends to occur when the economic growth rate in a country is low, inflation and real interest rates are high, there is vulnerability to balance-of-payment of the country, the country has an explicit deposit insurance scheme (DIS), and has weak law enforcement agency. The focus of another study by Demirguc-Kunt and Detragiache [3] is on the relationship between explicit DIS and banking crisis. That study shows that an explicit DIS increases the probability of a banking crisis. The probability is even higher when the DIS provides extensive coverage, it is funded, and run by the government, or the country's bank interest rates are deregulated. The study by Khan and Dewan [1] analyzes the effects of an explicit DIS on the banking crisis in a country while taking the country's overall economic development into consideration.

To our knowledge, as of today no study has defined the severity of a banking crisis by taking both the cost and the duration of the crisis into account while examining the factors associated with a banking crisis; or has shed light on the lag time between a banking problem and the revelation of a banking crisis. Hence, we felt the need for this study.

In order to determine the factors associated with a severe banking crisis, we examine various macroeconomic, financial, and institutional factors. Section 2 provides a brief theoretical underpinning for using a set of explanatory variables/factors in our model. These explanatory variables are GDP growth rate, terms of trade, depreciation rate, rate of inflation, ratio of M2 to foreign exchange reserves, growth rate of real domestic credit in the private sector, using of an explicit DIS, per capita GDP, and the remains of the past crisis. Formulation of these explanatory factors and their data sources are reported in Table A2 in the Appendix.

We have used a panel data set for a large number of countries from around the world for the period of 19802003 (we could not consider the recent banking crises experienced by the US and the European banking sectors for lack of necessary information to determine the severity of the banking crises). Unlike previous studies that used bi-variatelogit or probit model, we use an ordered logit model and find that the probability of a severe banking crisis is positively associated with an economic boom and a liberalized financial system when both variables are lagged by 4 years. It implies that banking problems start much earlier than the time when they are revealed. A possible explanation of that could be the fear of negative economic repercussions from early revelation. We also find that the longer the time-lag after the last crisis, the lower the remains of the crisis, and the higher the probability of a severe banking crisis. The factors such as the rate of inflation, the existence of an explicit DIS, and the country's weak institutional environment that other studies found to be associated with banking crisis, are also found to be positively associated with the severity of a banking crisis.

The remainder of this paper is structured as follows. The next section explains the data and the variables with a brief theoretical underpinning. Section three presents the estimation results and their robustness. Section four concludes.

\section{The Data and the Variables}

\subsection{Dependent Variable-Severe Banking Crisis}

We use Laeven and Valencia [5] as the source of data for severe banking crises. The severity of a crisis is determined by taking simple arithmetic average of the crisis-duration (in years) and the rank of percentage GDP

${ }^{1}$ See Khan and Dewan [1], and Demirguc-Kunt and Detragiache [2]-[4]. 
loss (PGL). The ranks for PGL are as follows: 0 if PGL $\leq 1,1$ if $1<\mathrm{PGL} \leq 20,2$ if $20<\mathrm{PGL} \leq 40$, and so forth. Hence, for instance, the severity of Argentine banking crisis is 3 as the crisis in 1980 lasted for 3 years (19801982), and its rank for PGL is 3 because of 58\% GDP loss.

The variable "Severe banking crisis" takes the value 0 , if a country didn't experience any banking crisis in a year; or else it takes the severity value as calculated. In order to avoid the simultaneity bias, we dropped the data for the duration of a crisis.

\subsection{Independent Variables}

\subsubsection{GDP Growth Rate and Economic Boom}

The contractionary phase of the business cycle can cause a banking sector problem [6] [7]. To measure the depth of economic contraction, we use the GDP growth rate. While a banking sector problem may happen concurrently with economic downturn, some suggest that an economic boom may precede a banking crisis [2]. Schwierz [8] suggests that "banking problems may be hidden for a long time until being detected and revealed by negative economic shocks". We use GDP growth rate with different lags to test whether or not a boom indeed takes place prior to a banking crisis. There may be a boost in export during an economic boom. Therefore, we also use lagged values of terms of trade to find the timing of economic boom before a banking crisis.

\subsubsection{Liberalized Financial System Prior to a Banking Crisis}

Many countries use liberalized financial system to stimulate domestic investment and economic growth by moving away from financial repression that reduces private credit [9] [10]. A large volume of studies find that a country's financial system remains liberalized prior to a banking crisis [3] [4]. Some studies, e.g., DemirgucKunt and Detragiache [2], use both the ratio of private credits to GDP and the growth of domestic credit as indicators of liberalized financial system. However, the first variable is found to be little, or not, significant [2]. The variable that we use in our model is used by Khan and Dewan [1], and it takes both of the variables from Demirguc-Kunt and Detragiache model into consideration. As private sector is the main beneficiary of a liberalized financial system, it makes sense to use the growth rate of private domestic credit as the indicator for liberalized financial system. We use the growth rate of private domestic credit with different lags to find the number of years it takes for a severe banking crisis to happen after financial system liberalization.

\subsubsection{Institutional Environment}

The institutional environment in a country is an important factor for a banking crisis. The institutional environment indicates the country's capability to take necessary measures to prevent or contain a banking crisis [11]. Besides per capita GDP, variables such as the corruption index and the law and order index are used to represent institutional environment in a country [1]-[3]. However, the impacts of these variables are found to be not significantly different from each other. Therefore, we prefer to use per capita GDP to represent the institutional environment in a country. It has several advantages over other indicators. Firstly, it better represents other kinds of institutional environments. For example, the higher the level of per capita GDP in a country, the better the country is capable of controlling corruption, maintaining the law and order condition, and reducing bureaucracy. Secondly, time series data for the corruption index and the law and order index are not available for many countries for long period of time, whereas the data on per capita GDP is readily available.

\subsubsection{Deposit Insurance Scheme (DIS)}

An explicit DIS seems to have two opposing effects on a banking crisis. According to Diamond and Dybvig [12], a DIS entails optimal policy to protect bank stability in an environment where the stability could be threatened by a self-fulfilling depositor run. On the other hand, some argue that bank managements under the net of DIS can take excessive risk in disbursing loans (moral hazard problem), leading to a banking crisis [1] [3]. Most of the studies ${ }^{2}$ that examined the factors associated with a banking crisis found the use of an explicit DIS by a country to be a highly significant factor for the banking crisis. Hence, the use of explicit DIS as an explanatory variable in our model is justified from both empirical and theoretical grounds. We use a dummy variable to examine the impact of explicit DIS (1 if a country uses explicit DIS, 0 otherwise).

${ }^{2}$ For instance, Demirguc-Kunt and Detragiache [2] [3], and Khan and Dewan [1]. 


\subsubsection{The Remains of a Past Banking Crisis}

Kindleberger [13] states that "some time must elapse after one speculative mania that ends in crisis before investors have recovered sufficiently from their losses and disillusionment to be willing to take a flyer again". One theory that is consistent with this view is that the more the time elapses after a banking crisis, the lower the residue of the crisis, and the less careful the central authority about the prudential regulation of the banking sector. It allows the bank managements to again disburse high-risk loans, which consequently increases the recurrence of a banking crisis. A contrary view is that the more the time elapses after a banking crisis, the more properly the crisis is addressed. That lowers the residue of the crisis, which effectively reduces the recurrence of another crisis. We attempt to test these contradictory views empirically.

\subsubsection{Other Independent Variables}

The high rate of inflation in a country can cause its financial market and economic condition to be fragile [14]. If the rate of inflation is high, the creditors and the depositors see financial loss from their money lent or deposited, which ultimately jeopardizes the financial system, and leads to a banking crisis [4].

The real interest rate is another influencing factor of financial market, and a contributing factor to banking crisis [2] [3]. A high real interest rate can cause the borrowers to default on their loans, which consequently can cause a banking crisis.

The large volume of currency in circulation relative to the foreign exchange reserve is also a strong indicator of the vulnerability of a country's financial market [15]. A country with good economic prospect or booming economic condition attracts foreign direct investments, bank loans, and such. These credits are invested in local currency. When the foreign creditors or investors sense the economic condition of the country to be fragile, or find alternative sources of higher financial gains from their investments, they withdraw (or tend to withdraw) their money from the country. This can cause serious problems for a country's financial sector.

\section{Empirical Evidence}

\subsection{Estimation Model}

As our dependent variable "Severe banking crisis" takes multiple values because of different severity levels of the crises, we use an ordered logit model for data analysis. Following is a brief description of our fitted model. See Green [16] for detail.

In the ordered logit model, the dependent variable $Y$ (in our case "Severe banking crisis") is an observed ordinal variable, where $Y$ is a function of an unobservable or latent variable, $Y^{*}$. The values of the latent variable $Y^{*}$ determine the values for the observed ordinal variable $Y$. The continuous latent variable $Y^{*}$ has various cut-off, or threshold, points. A value of the observed variable $Y$ depends on whether or not the value of $Y^{*}$ has crossed a particular cut-off point. Our dependent variable $Y$ takes 13 different values from 0 to 6 in 0.5 point increment. Therefore, the cut-off point, $\kappa$, takes 12 different values. The values of $Y_{i}$ are determined based on $Y_{i}^{*}$ as follows:

$$
\begin{aligned}
& Y_{i}=0 \text { if } Y_{i}^{*} \leq \kappa_{1} ; Y_{i}=0.5 \text { if } \kappa_{1}<Y_{i}^{*} \leq \kappa_{2} ; Y_{i}=1 \text { if } \kappa_{2}<Y_{i}^{*} \leq \kappa_{3} ; Y_{i}=1.5 \text { if } \kappa_{3}<Y_{i}^{*} \leq \kappa_{4} ; \\
& Y_{i}=2 \text { if } \kappa_{4}<Y_{i}^{*} \leq \kappa_{5} ; Y_{i}=2.5 \text { if } \kappa_{5}<Y_{i}^{*} \leq \kappa_{6} ; Y_{i}=3 \text { if } \kappa_{6}<Y_{i}^{*} \leq \kappa_{7} ; Y_{i}=3.5 \text { if } \kappa_{7}<Y_{i}^{*} \leq \kappa_{8} ; \\
& Y_{i}=4 \text { if } \kappa_{8}<Y_{i}^{*} \leq \kappa_{9} ; Y_{i}=4.5 \text { if } \kappa_{9}<Y_{i}^{*} \leq \kappa_{10} ; Y_{i}=5 \text { if } \kappa_{10}<Y_{i}^{*} \leq \kappa_{11} ; Y_{i}=5.5 \text { if } \kappa_{11}<Y_{i}^{*} \leq \kappa_{12} ; \\
& \text { and } Y_{i}=6 \text { if } Y_{i}^{*}>\kappa_{12} \text {. } \\
& \text { In a population, the continuous latent variable } Y^{*} \text { is defined as }
\end{aligned}
$$

$$
Y_{i}^{*}=\sum_{k=1}^{K} \beta_{k} \mathbf{X}_{k i}+\varepsilon_{i}=Z_{i}+\varepsilon_{i}
$$

where $\mathbf{X}$ is the vector of explanatory variables, $K$ is the number of explanatory variables, and $\varepsilon$ is the error term. $\varepsilon$ has a logistic distribution. $\beta$ s and $\kappa$ s are estimated by the ordered logit model. Once the values of $\beta$ s are estimated, we can compute

$$
Z_{i}=\sum_{k=1}^{K} \beta_{k} \mathbf{X}_{k i}
$$

We use the estimated twelve cut-off values to calculate the probabilities of 13 values of $Y$. For instance, 


$$
\begin{aligned}
& \operatorname{Prob}(Y=0 \mid \mathbf{X})=\frac{1}{1+\mathrm{e}^{\left(\mathbf{Z}_{\mathbf{i}}-\kappa_{1}\right)}}=\frac{1}{1+\mathrm{e}^{\left(\boldsymbol{\beta}^{\prime} \mathbf{X}-\kappa_{1}\right)}} \equiv F\left(\boldsymbol{\beta}^{\prime} \mathbf{X}, \kappa_{1}\right), \\
& \operatorname{Prob}(Y=0.5 \mid \mathbf{X})=\frac{1}{1+\mathrm{e}^{\left(\mathbf{z}_{\mathbf{i}}-\kappa_{2}\right)}}-\frac{1}{1+\mathrm{e}^{\left(\mathbf{Z}_{\mathbf{i}}-\kappa_{1}\right)}} \equiv F\left(\boldsymbol{\beta}^{\prime} \mathbf{X}, \kappa_{1}, \kappa_{2}\right), \\
& \operatorname{Prob}(Y=1 \mid \mathbf{X})=\frac{1}{1+\mathrm{e}^{\left(\mathbf{z}_{\mathbf{i}}-\kappa_{3}\right)}}-\frac{1}{1+\mathrm{e}^{\left(\mathbf{z}_{\mathbf{i}}-\kappa_{2}\right)}} \equiv F\left(\boldsymbol{\beta}^{\prime} \mathbf{X}, \kappa_{2}, \kappa_{3}\right), \\
& \quad \vdots \\
& \operatorname{Prob}(Y=5.5 \mid \mathbf{X})=\frac{1}{1+\mathrm{e}^{\left(\mathbf{z}_{\mathbf{i}}-\kappa_{12}\right)}}-\frac{1}{1+\mathrm{e}^{\left(\mathbf{Z}_{\mathbf{i}}-\kappa_{11}\right)}} \equiv F\left(\boldsymbol{\beta}^{\prime} \mathbf{X}, \kappa_{11}, \kappa_{12}\right), \\
& \operatorname{Prob}(Y=6 \mid \mathbf{X})=1-\frac{1}{1+\mathrm{e}^{\left(\mathbf{Z}_{\mathbf{i}}-\kappa_{12}\right)}} \equiv F\left(\boldsymbol{\beta}^{\prime} \mathbf{X}, \kappa_{12}\right) .
\end{aligned}
$$

The ordered logit model estimates the probability that the latent variable $Y^{*}$ falls between two threshold values by assuming a logistic distribution for the error term and using the estimated value of $Z$.

When interpreting the regression results of an ordered logit model, it is important to remember that an estimated coefficient does not indicate the direct increase in the probability of a crisis given a one-unit increase in the corresponding explanatory variable. Instead, the coefficient reflects the effect of a change in the explanatory variable on the probability function as mentioned above. However, the sign of the coefficient does indicate the direction of the change.

\subsection{Estimation Results}

The estimation results are reported in Table 1. The results show that the GDP growth rate and the terms of trade (the two indicators used to measure economic boom), when lagged by 4 years, are positively correlated with the probability of a severe banking crisis and are statistically significant at $6.6 \%$ and $3.4 \%$ level respectively. They

\begin{tabular}{|c|c|c|c|c|c|}
\hline \multicolumn{3}{|c|}{ Regression-1 } & \multicolumn{3}{|c|}{ Regression-2 } \\
\hline $\begin{array}{c}\text { Dep. var. = Severe } \\
\text { banking crisis }\end{array}$ & Coefficient & Std Error & $\begin{array}{c}\text { Dep. var. = Severe } \\
\text { banking crisis }\end{array}$ & Coefficient & Std Error \\
\hline GDP growth t-4 $_{1}$ & $0.0276^{*}$ & 0.0150 & GDP growth & $-0.1487^{* * *}$ & 0.0429 \\
\hline Inflation & $0.0017^{* *}$ & 0.0008 & Inflation & 0.0009 & 0.0008 \\
\hline Terms of trade $\mathrm{t}_{\mathrm{t}-4}$ & $1.0140^{* *}$ & 0.4780 & Terms-of-trade ${ }_{\mathrm{t}-4}$ & $0.9800^{* * *}$ & 0.3791 \\
\hline Real interest & -0.0001 & 0.0004 & Real interest & 0.0002 & 0.0003 \\
\hline M2/reserves & 0.0004 & 0.0008 & M2/reserves & 0.0013 & 0.0012 \\
\hline Credit growth $_{\mathrm{t}-4}$ & $0.0152^{* *}$ & 0.0070 & Credit growth $_{\mathrm{t}-4}$ & $0.0148^{* * *}$ & 0.0061 \\
\hline Per capita GDP & $-0.0895^{* *}$ & 0.0381 & Per-capita-GDP & $-0.1003^{* * *}$ & 0.0385 \\
\hline Remains of the past crises & $-5.7562^{*}$ & 3.0821 & Remains of the past crises & $-6.2215^{* *}$ & 3.1266 \\
\hline Existence of DIS & $0.8685^{* * *}$ & 0.35 & Existence of DIS & $0.9667^{* * *}$ & 0.3647 \\
\hline Obs & 1408 & & Obs & 1406 & \\
\hline Log likelihood & -308.7 & & Log likelihood & -299 & \\
\hline Wald chi $^{2}$ & 69.08 & & Wald chi $^{2}$ & 82.44 & \\
\hline Prob $>$ chi $^{2}$ & 0 & & Prob $>\mathrm{chi}^{2}$ & 0 & \\
\hline Pseudo $\mathrm{R}^{2}$ & 0.0511 & & Pseudo $\mathrm{R}^{2}$ & 0.0806 & \\
\hline
\end{tabular}
are not statistically significant when lagged by 1, 2 or 3 years (results can be obtained from the authors). This finding is consistent with the comment by Schwierz [8] that a banking crisis process may start much earlier, but may remain hidden until it is detected and revealed by negative economic shocks.

\section{Table 1. Estimating the factors associated with a severe banking crisis.}

${ }^{* * *},{ }^{* *}$ or ${ }^{*}$ indicates that the coefficient is significant at $1 \%, 5 \%$ or $10 \%$ level respectively. 
We find that the correlation coefficient between contemporaneous GDP growth rate and the severity of a banking crisis is negative (significant at 1\% level). It supports the theoretical view [6] [7] and the empirical findings [3] that banking crisis happens during economic downturn. After an economic boom when a country experiences a gradual economic downturn, and its economic growth rate becomes very low, it is then the country experiences a severe banking crisis. It could be noted here that we come to the same conclusion by using different dataset and methodology from those of other studies.

As theory suggests [9] [10], the high growth of domestic credits in the private sector (an indicator of a liberalized financial system) has a positive correlation with the severity of a banking crisis in our model. However, this variable is statistically significant only when lagged by 4 years. What we observe is that with a potentially good economic prospect, a country liberalizes its financial system in order to channel money to the investors and borrowers, but this liberalized financial system has a rather unexpected impact afterwards on the economy. It contributes to a banking crisis in a few years (4 years to be exact in our data).

We also find that the more the time elapses after a banking crisis, the lower the remains of the crisis, and the higher the probability of a severe banking crisis. A plausible explanation of this is that as time elapses after a banking crisis, policy-makers become more and more passive. That eventually leads to a severe banking crisis.

The rate of inflation is another factor that is positively associated with the severity of a banking crisis (significant at 5\% level). With a high rate of inflation, the lenders incur financial losses. As a result, many lenders/banks recall their loans or increase interest rates. These actions cause many firms to fail and the number of non-performing loans to increase, which contributes to a banking crisis [3] [4].

Khan, et al. [11] found that a country with weak institution was not capable of taking necessary measures to protect the country from a potential banking crisis, or a financial sector collapse. This study supports that finding by using new data and estimation technique. It shows that a country's institutional environment, measured by the GDP per capita, where higher per capita GDP means better institutional environment, is negatively associated with the severity of a banking crisis (significant at $2 \%$ level).

We also find that the existence of a DIS increases the probability of a severe banking crisis (significant at $1 \%$ level). This finding is consistent with the findings of several other studies about simple banking crisis that used bi-variatelogit/probit model [1] [3].

\subsection{Robustness of the Empirical Findings}

To check for the robustness of our results, we need to test for simultaneity bias or reverse causality problem for the contemporaneous variables (i.e. the variables without any lag or lead). We focus on the variables that are statistically significant in Regression-1 of Table 1, i.e. per capita GDP, DIS, and inflation for causality test.

Replacing per capita GDP with the level of corruption as an indicator for institutional environment in Regression-1 can solve one possible simultaneity bias problem. For the level of corruption in a country doesn't change frequently. It is very unlikely that the level of corruption would change immediately after a banking crisis. Using corruption $^{3}$ as an independent variable, we obtain the same relationship as before between the institutional environment and the probability of a severe banking crisis in a country (results can be obtained from the authors).

The adoption of DIS and a banking crisis may happen simultaneously, which creates causality problem. One can identify the causality run by using a two-stage estimation method. In the first stage, estimate the predicted value of the adoption of a DIS based on a set of explanatory variables, and call it DIS-predict. In the second stage, replace the DIS-dummy with the variable DIS-predict to estimate the probability of a severe banking crisis. See Khan and Dewan [1] for detail. The results show that the adoption of a DIS causes a banking crisis, not vice versa (results are not reported, but can be obtained from the authors).

To check for the causality run between inflation and banking crisis, we use a two-stage estimation method again. Stage 1: Using the OLS method, we estimate the predicted value of inflation based on a set of independent variables, where at least one variable is theoretically related to inflation but not to severe banking crisis. That variable is "Excess population growth rate," which is the difference between the population growth rate and the GDP growth rate.

Stage 2: Using the ordered logit estimation method, we estimate our benchmark regression equation (Regression-1) by replacing inflation rates with the predicted values of inflation (Inflation-predict) in the equation.

\footnotetext{
${ }^{3}$ Corruption indexes range from zero to six. The higher the index value, the lower the level of corruption. The data source is International Country Risk Guide. We have data until 1997; therefore, the 1997 corruption index is used for the years 1998 through 2003.
} 
The estimation result shows that the coefficient of Inflation-predict has the expected sign, and it is a highly significant factor for a severe banking crisis. It proves that a high inflation causes a severe banking crisis, not vice-versa (results can be obtained from the authors).

\section{Conclusions}

Instead of considering all banking crises alike, in this study, we differentiate among the crises based on their severities. The severities are measured by the costs and the durations of the crises. Using an ordered logit model, we identify the factors that are associated with a severe banking crisis.

The most significant finding of this study is that a severe banking crisis is associated with an economic boom and financial system liberalization when both variables are lagged by 4 years. It implies that the process of a banking crisis starts much earlier than when it is revealed [8]. It could be kept hidden for several reasons. Firstly, not to reveal the administrative and/or managerial weaknesses that caused the financial institutions to be in problems. Secondly, it might not be revealed due to time inconsistency problem. Quite often there is political interest such as being afraid of losing popularity. That forces the policy-makers not to reveal the financial market problems timely. As the necessary measures are not taken at the onset of the financial market problems, they get much worse when they are detected and revealed.

This study suggests that the policy-makers ought to be careful during an economic boom, especially when the country has a liberalized financial system. Sustainable economic growth with a secured and non-vulnerable financial system is certainly better than a rapid but unsustainable economic boom with a shaky liberalized financial system. Many firms take advantage of liberalized financial channels and invest money in risky projects. As a result, productions increase to have an economic boom, but the economic boom does not last long as the productions from the projects are not sustainable and the projects eventually fail. In most cases, projects struggle for a long time before they fail. The financial institutions that lent money to the struggling projects start to feel the bites during that period. Once the projects fail, the financial market’s problems get worse. The policy-makers' timely and prudent measures about a liberalized financial system are essential to avoid imminent problems in the financial sector.

Another important finding of this study is that the more the time elapses after a banking crisis, the less the remains of the crisis, and the higher the probability of the recurrence of a severe crisis. We argue that as the past crisis gets older, the policy-makers are less vigilant about the stability of the financial market, which causes another banking crisis to start. We suggest that once a country experiences a banking crisis, efforts for a stable banking sector should be continued even after the crisis is resolved. Prudential financial market regulation, timely supervision with necessary stringent actions against problematic financial institutions should be inevitable part of the financial market management policy for all the time.

A few other findings of this study are not different from those in other studies. For instance, we also find that a high rate of inflation, a weak institutional environment, and the existence of a DIS are associated with the severity of a banking crisis. Therefore, we recommend price stability, transparent institutional environment, and a prudentially regularized and supervised DIS for a stable banking sector.

One limitation of this study is that we could not include the most recent banking crises experienced by the US and the European banking sectors due to the lack of complete data on crisis-cost and crisis-duration. We will extend this study when that data becomes available.

\section{References}

[1] Khan, A.H. and Dewan, H. (2010) Deposit Insurance Scheme (DIS) and Banking Crises: A Special Focus on Less Developed Countries. Journal of Empirical Economics, 41, 155-182. http://dx.doi.org/10.1007/s00181-010-0438-8

[2] Demirgúc-Kunt, A. and Detragiache, E. (1999) The Determinants of Banking Crises: Evidence from Industrial and Developing Countries. Policy Research Working Paper Series, The World Bank, Washington DC.

[3] Demirgúc-Kunt, A. and Detragiache, E. (2002) Does Deposit Insurance Increase Banking System Stability? An Empirical Investigation. Journal of Monetary Economics, 49, 1373-1406. http://dx.doi.org/10.1016/S0304-3932(02)00171-X

[4] Demirgúc-Kunt, A. and Detragiache, E. (2005) Cross-Country Empirical Studies of Systemic Bank Distress: A Survey. Policy Research Working Paper Series, The World Bank, Washington DC.

[5] Laeven, L. and Valencia, F. (2010) Resolution of Banking Crises: The Good, the Bad, and the Ugly. Working Paper, 
IMF.

[6] Kaminsky, G.L. and Reinhart, C.M. (1999) The Twin Crises: The Causes of Banking and Balance of Payments Problems. American Economic Review, 89, 473-500. http://dx.doi.org/10.1257/aer.89.3.473

[7] Gorton, G. (1988) Banking Panics and Business Cycles. Oxford Economic Papers, 40.

[8] Schwierz, C. (2004) Economic Costs Associated with the Nordic Banking Crises. The Norwegian Banking Crisis, Occasional Papers, Oslo.

[9] McKinnon, R.I. (1973) Money and Capital in Economic Development. Brookings Institution, Washington DC.

[10] Shaw, E. (1973) Financial Deepening in Economic Development. Oxford University Press, Oxford.

[11] Khan, A.H., Khan, H.A. and Dewan, H. (2013) Central Bank Autonomy, Legal Institutions and Banking Crisis Incidence. International Journal of Finance and Economics, 18, 51-73. http://dx.doi.org/10.1002/ijfe.456

[12] Diamond, D. and Dybvig, P. (1983) Bank Runs, Deposit Insurance and Liquidity. Journal of Political Economics, 91, 401-419. http://dx.doi.org/10.1086/261155

[13] Kindleberger, C.P. (2000) Manias, Panics and Crashes: A History of Financial Crises. 4th Edition, John Wiley and Sons, New York.

[14] Obstfeld, M. (1986) Rational and Self-Fulfilling Balance-of-Payment Crises. American Economic Review, 76, 72-81.

[15] Calvo, G.A. (1998) Varieties of Capital-Market Crises. In: Calvo, G.A. and King, M., Eds., The Debt Burden and Its Consequences for Monetary Policy, Macmillan Press, New York.

[16] Green, W.H. (2011) Econometric Analysis. 7th Edition, Prentice Hall, London.

[17] Demirgúc-Kunt, A., Karacaovali, B. and Laeven, L. (2005) Deposit Insurance around the World: A Comprehensive Database. Policy Research Working Paper Series, The World Bank, Washington DC.

[18] Caprio, G. and Klingebiel, D. (2003) Episodes of Systemic and Borderline Financial Crises. In: Klingebiel, D., Ed., The World Bank, Washington DC. 
Appendix

Table A1. Countries with severities of crises.

\begin{tabular}{|c|c|c|c|c|c|}
\hline Country & Crisis began & Crisis-duration (in yrs.) & Crisis-cost & Cost-ranking & Severity of crisis \\
\hline Argentina & 1995 & 1 & 0 & 0 & 0.5 \\
\hline Argentina & 1980 & 3 & 58 & 3 & 3 \\
\hline Argentina & 2001 & 4 & 71 & 4 & 4 \\
\hline Bolivia & 1994 & 1 & 0 & 0 & 0.5 \\
\hline Bolivia & 1986 & 1 & 49 & 3 & 2 \\
\hline Brazil & 1990 & 5 & 62 & 4 & 4.5 \\
\hline Cameroon & 1987 & 5 & 106 & 6 & 5.5 \\
\hline Chile & 1981 & 5 & 9 & 1 & 3 \\
\hline Colombia & 1982 & 1 & 47 & 3 & 2 \\
\hline Colombia & 1998 & 3 & 43 & 3 & 3 \\
\hline Finland & 1991 & 5 & 70 & 4 & 4.5 \\
\hline India & 1993 & 1 & 0 & 0 & 0.5 \\
\hline Indonesia & 1997 & 5 & 69 & 4 & 4.5 \\
\hline Jamaica & 1994 & 3 & 38 & 2 & 2.5 \\
\hline Japan & 1991 & 5 & 45 & 3 & 4 \\
\hline Jordan & 1989 & 3 & 106 & 6 & 4.5 \\
\hline Kenya & 1985 & 1 & 24 & 2 & 1.5 \\
\hline Kenya & 1992 & 3 & 50 & 3 & 3 \\
\hline Korea & 1997 & 2 & 58 & 3 & 2.5 \\
\hline Kuwait & 1980 & 4 & 143 & 8 & 6 \\
\hline Malaysia & 1997 & 3 & 31 & 2 & 2.5 \\
\hline Mexico & 1994 & 3 & 14 & 1 & 2 \\
\hline Мexico & 1981 & 5 & 27 & 2 & 3.5 \\
\hline Morocco & 1980 & 5 & 22 & 2 & 3.5 \\
\hline Nepal & 1988 & 1 & 0 & 0 & 0.5 \\
\hline Nicaragua & 2000 & 2 & 0 & 0 & 1 \\
\hline Nigeria & 1990 & 5 & 0 & 0 & 2.5 \\
\hline Norway & 1987 & 3 & 5 & 1 & 2 \\
\hline Panama & 1988 & 2 & 85 & 5 & 3.5 \\
\hline Paraguay & 1995 & 1 & 15 & 1 & 1 \\
\hline Peru & 1983 & 1 & 55 & 3 & 2 \\
\hline Philippines & 1997 & 5 & 0 & 0 & 2.5 \\
\hline Philippines & 1981 & 4 & 92 & 5 & 4.5 \\
\hline Senegal & 1988 & 4 & 6 & 1 & 2.5 \\
\hline Sierra Leone & 1990 & 5 & 34 & 2 & 3.5 \\
\hline Sri Lanka & 1989 & 3 & 20 & 1 & 2 \\
\hline Swaziland & 1995 & 5 & 46 & 3 & 4 \\
\hline Sweden & 1991 & 5 & 33 & 2 & 3.5 \\
\hline Thailand & 1983 & 1 & 25 & 2 & 1.5 \\
\hline Thailand & 1997 & 4 & 109 & 6 & 5 \\
\hline Togo & 1993 & 2 & 39 & 2 & 2 \\
\hline Tunisia & 1991 & 1 & 1 & 1 & 1 \\
\hline Turkey & 2000 & 2 & 37 & 2 & 2 \\
\hline United States & 1984 & 1 & 0 & 0 & 0.5 \\
\hline Uruguay & 2002 & 4 & 27 & 2 & 3 \\
\hline Uruguay & 1981 & 5 & 38 & 2 & 3.5 \\
\hline Venezuela, Rep. Bol. & 1994 & 5 & 1 & 1 & 3 \\
\hline Yemen, Republic of & 1996 & 1 & 16 & 1 & 1 \\
\hline Zimbabwe & 1995 & 5 & 10 & 1 & 3 \\
\hline
\end{tabular}

Severity of crisis is the average of crisis-duration and cost-ranking. Crisis-cost is measured in terms of the percentage of GDP lost during the crisis. For cost-ranking, we used 1 for 1\% - 20\% GDP loss, 2 for $21 \%$ - 40\% GDP loss, and so on. 
Table A2. Formulation and data sources of the variables.

\begin{tabular}{|c|c|c|}
\hline Variable & Formulation & Source \\
\hline GDP growth & $\begin{array}{c}=\left\{\left(G_{t}-G_{t-1}\right) / G_{t-1}\right\} * 100, G_{t}=g /(\text { GDP deflator }) \text { at time } t \text {, where } g=\text { yearly } \\
\text { GDP at current price }\end{array}$ & IFS \\
\hline Terms of trade & $\begin{array}{c}=E / I \text { where } E \text { and } I \text { is the total merchandise-export value and total merchandise-import } \\
\text { value respectively }\end{array}$ & IFS \\
\hline Inflation & $=\left\{\left(p_{t}-p_{t-1}\right) / p_{t-1}\right\} * 100$, where $p=$ consumer price index & IFS \\
\hline Real interest & $\begin{array}{c}=d-i \text { where } d=\text { central bank discount rate (nominal deposit rate, money market rate, treasury } \\
\text { bill rate, govt. bond rate, saving rate, or lending rate, if the previous one is not available) and } i= \\
\text { contemporaneous rate of inflation }\end{array}$ & IFS \\
\hline M2/Reserves & $\begin{array}{l}=\mathrm{M} 2 / F, \text { where } \mathrm{M} 2=\text { the broad money drawn from line } 34+\text { the quasi-money drawn from line } 35 \\
\text { from IFS data series, and } F=\text { foreign exchange reserves; both converted into national currency }\end{array}$ & IFS \\
\hline Credit growth & $\begin{array}{c}=\left\{\left(\mathrm{PVTC}_{t}-\mathrm{PVTC}_{t-1}\right) / \mathrm{PVTC}_{t-1}\right\} \text { and } \mathrm{PVTC}_{t}=\mathrm{PVTl} / \mathrm{cpi} \text { at time } t \text {, where } \mathrm{PVTl}=\text { total } \\
\text { domestic-credit used by private sectors and cpi }=\text { consumer price index }\end{array}$ & IFS \\
\hline GDP per capita & Ratio of GDP (in US Dollar) to total population & IFS \\
\hline Existence of DIS & 1 if explicitly formed DIS exists in a country, 0 otherwise & $\begin{array}{l}\text { Demirguc-Kunt } \\
\quad \text { et al. [17] }\end{array}$ \\
\hline $\begin{array}{l}\text { Remains of the } \\
\text { past crisis }\end{array}$ & $\begin{array}{l}0 \text { if there wasn't any past crisis; otherwise, the inverse of the period (in years) between two crises. } \\
\text { Note that the past crises considered are the crises that took place in the 1980s and the 1990s. }\end{array}$ & $\begin{array}{c}\text { Caprio \& } \\
\text { Klingebiel [18] }\end{array}$ \\
\hline
\end{tabular}

List of the countries used for Regression-1 in Table 1:

Argentina, Armenia, Australia, Austria, Bahrain, Bangladesh, Barbados, Belgium, Belize, Benin, Bhutan, Bolivia, Botswana, Brazil, Burkina Faso, Burundi, Cambodia, Cameroon, Canada, Cape Verde, Chile, Colombia, Croatia, Cyprus, Côte d’Ivoire, Denmark, Dominican Republic, Egypt, El Salvador, Estonia, Fiji, Finland, France, Germany, Greece, Guatemala, Haiti, Honduras, Hungary, Iceland, India, Indonesia, Ireland, Israel, Italy, Jamaica, Japan, Jordan, Kazakhstan, Kenya, Korea, Kuwait, Kyrgyz Republic, Lesotho, Lithuania, Luxembourg, Madagascar, Malawi, Malaysia, Malta, Mauritius, Mexico, Mongolia, Morocco, Myanmar, Namibia, Nepal, Netherlands, New Zealand, Nicaragua, Nigeria, Norway, Oman, Pakistan, Panama, Papua New Guinea, Paraguay, Peru, Philippines, Poland, Portugal, Rwanda, Saudi Arabia, Senegal, Seychelles, Sierra Leone, Singapore, Slovenia, South Africa, Spain, Sri Lanka, St. Lucia, Swaziland, Sweden, Switzerland, Thailand, Togo, Trinidad and Tobago, Tunisia, Turkey, United Kingdom, United States, Uruguay, Venezuela, Yemen, and Zimbabwe.

NB: Countries are dropped from the regression if they are centrally planned or socialist states ${ }^{4}$, subservient states $^{5}$, states affected by civil war ${ }^{6}$, or if the data are missing on the variables that we use. Furthermore, parts of the study period for some countries are dropped because of their very transitional state of nature ${ }^{7}$.

\footnotetext{
${ }^{4}$ China, Cuba, Laos, and Vietnam.

${ }^{5}$ Hong Kong, Micronesia, and Taiwan.

${ }^{6}$ Afghanistan, Somalia, and Sudan.

${ }^{7}$ We exclude only the first two years for transitional economies when they transitioned from the centrally planned economy to the market economy.
} 
Scientific Research Publishing (SCIRP) is one of the largest Open Access journal publishers. It is currently publishing more than 200 open access, online, peer-reviewed journals covering a wide range of academic disciplines. SCIRP serves the worldwide academic communities and contributes to the progress and application of science with its publication.

Other selected journals from SCIRP are listed as below. Submit your manuscript to us via either submit@scirp.org or Online Submission Portal.
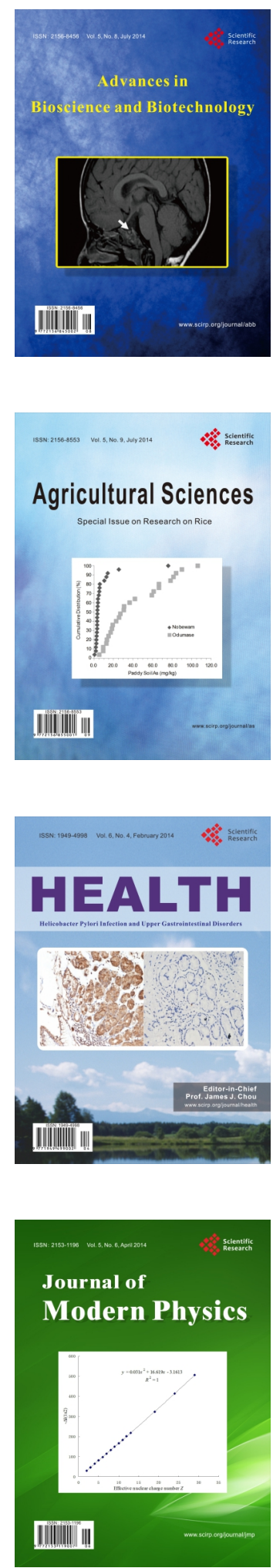
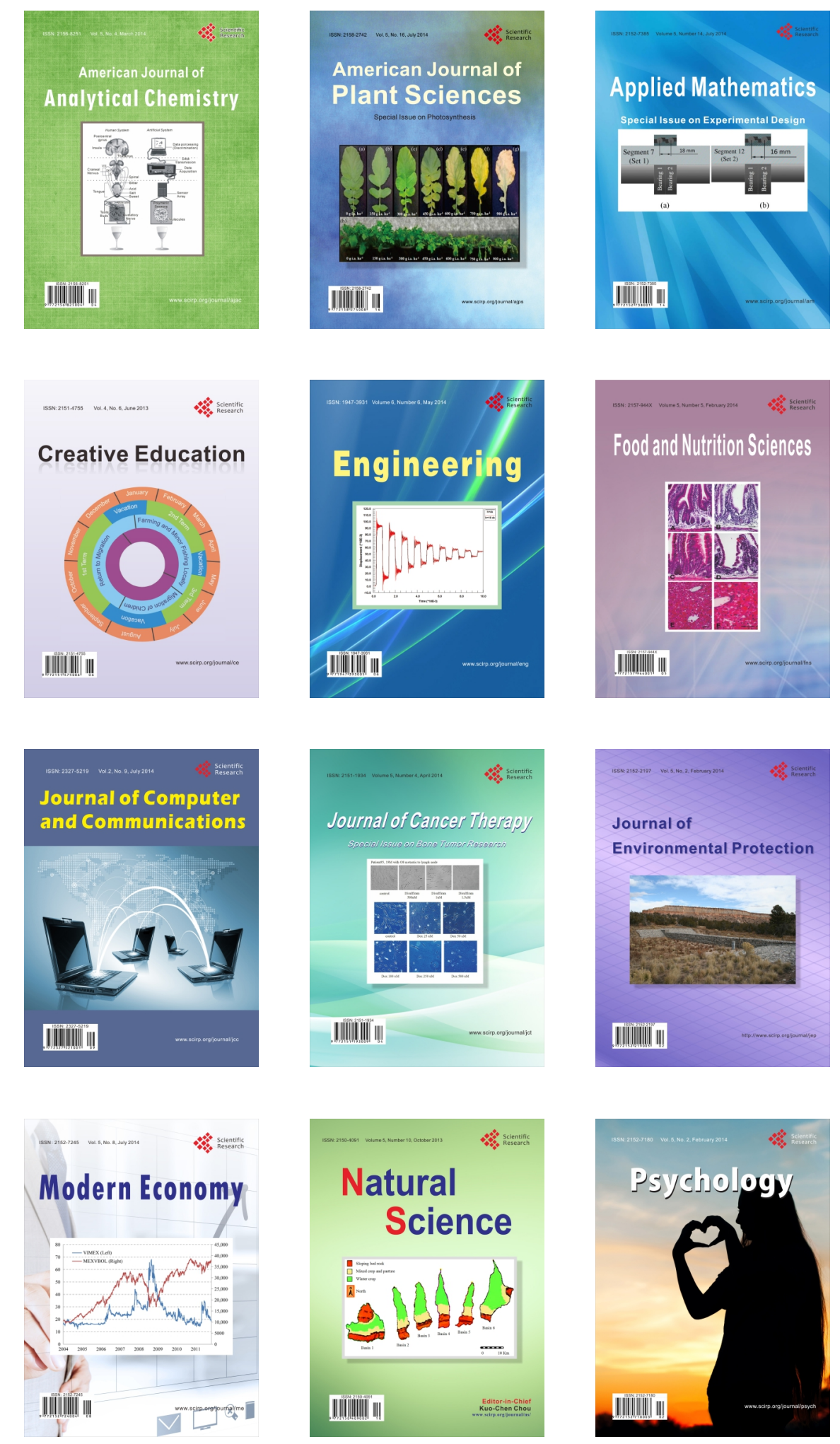